Пономарева $M$. А. Образы отношений дворянства и крестьянства в русской либеральной литературе в конце XIX - начале XX веков / М. А. Пономарева // Научный диалог. 2021. — № 4. — C. 391 - 409. — DOI: 10.24224/2227-1295-2021-4-391-409.

Ponomareva, M. A. (2021). Images of Relations between Nobility and Peasantry in Russian Liberal Literature in Late $19^{\text {th }}$ — Early 20th Centuries. Nauchnyi dialog, 4: 391-409. DOI: 10.24224/2227-1295-2021-4-391-409. (In Russ.).

\section{Образы отношений} дворянства и крестьянства в русской либеральной литературе в конце XIX начале XX веков

\author{
Пономарева Мария Александровна \\ orcid.org/0000-0001-8135-3067 \\ ResearcherID M-1122-2016 \\ Scopus Author ID 6603544114 \\ доктор исторических наук, доцент, \\ заведующая кафедрой отечественной \\ истории XX-XXI веков \\ ponomariya@sfedu.ru
}

Южный федеральный университет (Ростов-на-Дону, Россия)

\section{Images of Relations between Nobility and Peasantry in Russian Liberal Literature in Late $19^{\text {th }}$ - Early 20th Centuries}

Maria A. Ponomareva orcid.org/0000-0001-8135-3067

ResearcherID M-1122-2016

Scopus Author ID 6603544114

Doctor of History, Associate Professor, Head of the Department of Russian History of the XX-XXI centuries ponomariya@sfedu.ru

Southern Federal University (Rostov-on-Don, Russia)

(C) Пономарева М. А., 2021 


\section{ОРИГИНАЛЬНЫЕ СТАТЬИ}

\section{Аннотация:}

Статья посвящена особенностям отображения отношений дворянства и крестьянства в русской либеральной мысли рубежа $\mathrm{XIX-XX} \mathrm{веков.} \mathrm{Выполнен} \mathrm{обзор} \mathrm{истори-}$ ографии по проблеме, основное внимание уделено складывавшейся с середины 1980$\mathrm{x}$ годов традиции изучения либеральной интеллигенции в России и особенностей взаимоотношений «образованного меньшинства и крестьянского мира», представлен анализ новейшей научной литературы. Особое внимание уделено основным подходам к изучению темы, выделены микроисторический, позиционный и другие подходы, концепция «новой локальной истории». Заявлена необходимость их комплексного использования. Представлены результаты сравнительного анализа различных групп источников: воспоминаний и мемуаров, периодической печати, статистических материалов, переписки. Поднимается вопрос о различиях в самоидентификации российского дворянства, а также во взаимных представлениях двух важнейших сословий пореформенной России. Новизна исследования видится в том, что на основе новых методологических подходов выделены несколько образов отношений дворянства и крестьянства на рубеже XIX-XX веков: «предпринимательский», «попечительский», «барский»; даны их отличительные характеристики. Предлагаемая классификация обусловлена основными представлениями российского дворянства о крестьянах в условиях институционализации либеральной идеологии.

\section{Ключевые слова:}

дворянство; крестьянство; пореформенная Россия; образы отношений; либеральная литература; либеральная интеллигенция; земство.

\section{ORIGINAL ARTICLES}

\section{Abstract:}

The article is devoted to the peculiarities of the representation of relations between the nobility and the peasantry in Russian liberal thought at the cusp of XIX$\mathrm{XX}$ centuries. A review of the existing historiography on the problem is carried out, the main attention is paid to the emerging from the middle 1980s the traditions of studying the liberal intelligentsia in Russia and the peculiarities of the relationship between the "educated minority and the peasant world", an analysis of the latest scientific literature is presented. Special attention is paid to the main research approaches to the study of the topic, microhistorical, positional and other approaches, the concept of "new local history" is highlighted and the need for their complex use is declared. The results of a comparative analysis of various groups of sources are presented: reminiscence and memoirs, periodicals, statistical materials, correspondence. The question is raised about the differences in the self-identification of the Russian nobility, as well as in the mutual representations of the two most important estates of post-reform Russia. The novelty of the study is seen in the fact that, on the basis of new methodological approaches, several images of relations between the nobility and the peasantry have been identified at the cusp of XIX - XX centuries: the image of the "new entrepreneurial type", "guardianship" and "preservation of traditions", conventionally "lordly", as well as the image of "free action"; their distinctive characteristics are given. The proposed classification is due to the main ideas of the Russian nobility about the peasants in the context of the institutionalization of liberal ideology.

\section{Key words:}

nobility; peasantry; post-reform Russia; images of relationships; liberal literature, liberal intelligentsia; zemstvo. 


\section{Образы отношений дворянства и крестьянства в русской либеральной литературе в конце XIX — начале XX веков}

Пономарева М. А., 2021

\section{1. Введение: историография и методология изучения}

К началу XX века прошло уже несколько десятилетий после крестьянской реформы, резко изменившей жизнь значительной части населения страны. Отношения между дворянством как первенствующим сословием России и крестьянством в связи с нерешенностью множества аграрных проблем особенно обострились. К этому времени при еще существующем земском варианте либерализма постепенно институционализируются различные варианты либеральной идеологии. Как верно отметила М. Могильнер, «освобожденные из крепостной зависимости крестьяне вливались в “общество”, меняя его очертания, заставляя лидеров общественного мнения размышлять в протонациональных категориях, описывающих единое национально-государственное тело» [Могильнер, 2008, с. 16]. Лидерами общественного мнения в конце XIX - начале XX веков, безусловно, являлась интеллигенция, дворяне так называемого «нового типа», принявшие и адаптировавшиеся к новым экономическим отношениям в деревне, а также широкий круг представителей земского движения, среди которого было немало помещиков крупной и средней руки. Развитие пореформенной России определяли противоречивые отношения между двумя ведущими социальными слоями общества - дворянством и крестьянством. Каждый из этих слоев переживал активный процесс расслоения, связанный со стремительным развитием новых экономических условий. Взаимные постоянно преобразующиеся представления двух основных социальных слоев пореформенной России - крестьянства и дворянства, представляют интерес для современных исследователей как возможность изучения форм и направлений социальной трансформации модернизирующихся сообществ.

В советской доперестроечной исторической науке либерализм рассматривался как негативная тенденция общественно-политического развития страны. Поражение либералов в политической борьбе оценивалось как закономерный результат, изначально заложенный в реформистской теории и практике либерализма. Главным мерилом ценности выступала ленинская концепция революционного прогресса. Генезис русского либерализма изучался главным образом в трех вариантах: как часть истории русской общественной мысли (исследование либеральных идей и течений до конца 
XIX века); развитие земского либерализма как одной из сословных организационных форм в период с 1864 по 1905 годы; эволюция буржуазных политических партий и организаций в начале XX века (главное внимание уделялось в основном политическим партиям, преимущественно кадетам). Пристальное изучение заявленного вопроса началось в России в середине 1980-х годов, что было обусловлено как процессами, происходившими в стране, так и особенностями развития российской исторической литературы, в которой все большее внимание уделялось не героическому индивиду, а личности как внутреннему духовному сосуду. Проблемы комплексного изучения либерализма как самостоятельной идеологической и политической силы были подняты в середине 1980-х годов Н. М. Пирумовой и К. Ф. Шацилло. Монография Н. М. Пирумовой была посвящена истории возникновения, становления и развития одной из групп русской интеллигенции - служащих земств, так называемого «третьего элемента» [Пирумова, 1986]. Важность исследования данной темы определялась значением земской оппозиции, роль которой в условиях России трудно переоценить. Кроме того, в период с 1864 по 1895 годы именно земство выражало все многообразие либеральных идей и являлось организационной базой русского либерализма, носителями идеалов которого выступали ориентированные на развитие капиталистических отношений представители дворянства. Широким общественным движением, к которому в 1890х годах примыкала земская интеллигенция, оставалось либеральное народничество. К. Ф. Шацилло одним из первых обратил внимание на «новый либерализм», появившийся в России в начале XX века и ведущий свое начало от «легального марксизма» [Шацилло, 1985]. Автор вступил в полемику с Е. Д. Черменским, который еще в конце 1930-х годов рассматривал либерализм данного периода как внутреннее единое течение, носившее исключительно земскую окраску [Черменский, 1939].

В 1995 году в РГГУ прошла конференция «Россия в новое время. Образованное меньшинство и крестьянский мир: поиск диалога», на которой был представлен широкий спектр мнений по изучаемому вопросу. В частности, была высказана идея, что русская интеллигенция - типичная маргинальная группа, ощутившая неинтегрированность России ни в европейский, ни в азиатский мир как особенность, неповторимость страны. В связи с этим интеллигенция проявляла несколько типов поведения, каждый из которых базировался на чувствах разочарования и вины, порожденных несоответствием результатов и ожиданий. Во-первых, непосредственное служение народу путем подражания ему, а в конечном счете - слияние с ним, данная позиция может выглядеть одинаково у людей политически и идейно глубоко различных. Во-вторых, полный разрыв с национальны- 
ми традициями и культурными корнями, подчеркнутый космополитизм, «гражданство мира». Тем самым - частичная компенсация чувства вины и неудовлетворенности жизнью, полный разрыв с властью, уход в подполье, в оппозицию, в диссидентство. Очень сильно развито ощущение социальной не востребованности и мысль о вечном противостоянии интеллигенции и власти. В-третьих, теория «малых дел»; она позволяет сблизить две оценочные установки: служение людям и служение Отечеству. Но ни одна стратегия не интегрирует интеллигенцию ни в народ, ни во власть, поскольку в тоталитарном обществе интеллигенция не нужна как посредник, поэтому она уничтожается или вырождается, а в демократическом превращается в слой специалистов - интеллектуалов, выполняющих профессиональные функции [Баландина, 1995, с. 7-9]. Иная точка зрения в отношении российских либералов была представлена Л. В. Селезневой, которая утверждала, что, оставаясь западниками, они признавали глубокое своеобразие русского исторического процесса, который коренился в общинном укладе из-за запаздывания в историческом развитии страны. При этом общинный уклад, по мнению либералов, должен был смениться новыми формами социально-экономической жизни, импульсом к чему должны были послужить демократические политические институты, грамотность и политическая свобода. Интеллигенция стояла на реальной почве, но недооценивала традиционный менталитет российского крестьянства. Раскол национальной культурной традиции, заключавшийся в существенной разнице между традиционной ментальностью крестьянства и либеральной ментальностью российской интеллигенции, определил ход исторического развития России в начале ХХ века [Селезнева, 1995, с. 59-60].

Как верно отметил А. П. Логунов, в историографии 1990-х годов наблюдались две тенденции по переосмыслению российской истории: ликвидация «белых пятен» по направлению постановки и разработки вопросов и проблем, либо не вовлекавшихся ранее в орбиту научных интересов, либо остававшихся далеко на периферии. В результате на исторической арене появились новые деятели и оттенки, в научных спорах процессы развития стали преобладать над регрессом и застоем и даже слова менялись с борьбы, эксплуатации на термины: поиск, реформа и т. п.; стремление найти иной ключ к объяснению своеобразия российской истории, в результате чего научная деятельность направилась по новому руслу — изучение духовного развития и российской ментальности. Однако характерными чертами стали и предметная модернизация исторического материала, и попытки придания современной действительности общеисторического значения [Логунов, 1995, с. 3-6]

Проблема дуализма российской истории, «ее единства» была поставлена еще в классической российской историографической литературе. Переход от 
«традиционного» к «цивилизационному» обществу характеризуется в Европе появлением средних классов, а в России - все более усиливающейся конфликтностью между «образованным меньшинством» и основным населением (в основном, крестьянством), и этот процесс основывался на общенациональном диалоге. Оба участника этого диалога были активны и готовы к взаимодействию, однако каждый из них стремился «навязать» собственное миропонимание: «образованное меньшинство» - что народ непросвещен, необразован, не готов к осознанию собственных приоритетов и к самореализации. Отсюда дистанцирование от народа, сострадание ему, что привело к попытке ограничения негативных черт народной активности во имя его же блага, поиску для мобилизации позитивных народных черт, и весь этот процесс в результате закончился разочарованием для «образованного меньшинства». Речь может идти не о диалоге с народом, а о диалоге с образом народа. Крестьянский мир жил, в свою очередь, ожиданием решений сверху, при этом замыкаясь, но и давя на власть и «образованное меньшинство» как неотъемлемый компонент власти. В результате и с этой стороны имело место несовпадение ожиданий и реалий. Главная закономерность, по мнению А. П. Логунова, заключалась в следующем: чем дальше внешне, тем ближе внутренне [Логунов, 1995, с. 3-6]. К концу 1990-х годов, несмотря на наличие дискуссионных вопросов, состоялось первое обобщение имевшихся подходов, сформулированы общие выводы [Либерализм ..., 1996; Российский либерализм ..., 2004].

В новейшей историографии взгляды российского дворянства на роль и место крестьян в условиях новой России стали предметом изучения исследователей как в рамках проблем, связанных с особенностями реализации аграрной модернизации страны [Шаповалов и др., 2012, с. 99-104], так и в рамках изучения взглядов конкретных представителей либерального дворянства, представителей земств, либеральной интеллигенции [Пономарева, 2004]. Данный вопрос ставится при изучении проблем развития общественного движения в России в данный период в целом [Дмитриева, 2020, с. 292 - 299] и дворянства и крестьянства как отдельных социальных слоев, в частности [Кузьмин, 2007].

Новейший этап историографии социального развития России данного периода был определен научным спором об особенностях складывания уровня благосостояния крестьянства в России, развернувшимся вокруг публикации научной работы Б. Н. Миронова «Благосостояние населения и революции в имперской России: XVIII — начало XX века», в которой автор представил картину социального развития России с конца XVIII по 1917 год [Миронов, 2013, с. 136-144]. Наконец, в монографическом исследовании Н. С. Цинцадзе раскрываются вопросы историографии различных аспектов 
социально-экономической истории пореформенной России, в частности, особенности восприятия демографических и экологических последствий аграрной модернизации страны во второй половине XIX — начале XX века различными социальными и профессиональными группами: крестьянством, земскими деятелями, учеными, чиновниками, государственными и общественно-политическими деятелями, интеллигенцией [Цинцадзе, 2012].

Учитывая сложившееся поле исторического анализа, в данном исследовании мы опираемся на подход, описанный М. Блоком, согласно которому история является наукой о людях во времени [Блок, 1986]. Интерпретативный поворот в гуманитарных исследованиях позволяет нам сосредоточиться на микроисторических сюжетах, на основе которых проанализировать представления российского дворянства о своем «Я» и о «другом» - крестьянах, при этом учитывая, что «в более широкие поведенческие связи могут быть включены также и чувственные понятия, религиозные представления и коммуникативные формы» [Бахманн-Медик, 2017, с. 78]. В данном контексте применимы подходы так называемой «новой локальной истории», подразумевающие восприятие мира через оппозицию «своего» и «чужого», обозначение границы, как отделения «нашего места» от «их места» [Лотман, 1996, с. 174]. Граница всегда более аморфна, следовательно, более восприимчива к влиянию иных культур. Она достаточно уязвима для вторжения извне, но одновременно обеспечивает «непрерывающийся диалог» между пограничными культурами [Маловичко и др., 2003, с. 6-7]. Данный подход позволяет выявить внутренние мотивы, интеллектуальные усилия, личное целеполагание и психологию авторов исторического нарратива в рассматриваемый период. Кроме того, при анализе взглядов на крестьянство российского дворянства мы считаем необходимым исходить из положений так называемого «позиционного подхода», согласно которому существует значимая связь между должностью (позицией), занимаемой индивидом или группой, и возможностью принимать ими значимые для общества решения, распоряжаться общественными ресурсами [Mills, 1956]. Наконец, формирование и изображение идентичности предполагает соответствующий способ представления истории как непрерывного потока, плавно перетекающего из прошлого в современность [Конструирование ..., 2019, с. 7]. В связи с этим представляется интересным на основе сложившегося комплекса методологических подходов выделить основные образы отношений дворянства и крестьянства в русской либеральной литературе исходя из двух основных условий: процесс развития основных черт и особенностей мировоззрения дворян, их взглядов на российское крестьянство, его место и роль в пореформенной России, а также выявление зависимости между данными взглядами и 
структурой социального расслоения самого слоя земледельческой элиты конца XIX - начала XX веков, особенностей взаимоотношений различных типов российского дворянства с крестьянами в изменившихся социально-экономических и политических условиях.

\section{2. «Предпринимательский», «попечительский», «барский» образы отношений между российским дворянством и крестьянством}

О различных образах отношений между дворянами и крестьянами упоминается в очерке «Люди провинции». В данном эссе, напечатанном в журнале «Вестник Европы» в 1885 году, автор описывает встречу с предприимчивым мелкопоместным дворянином Кубриным. Главная задача автора заметок - выяснить, каким образом у него получается при малом количестве земли, не имея крепостных, увеличивать капитал и какую роль в этом играют его взаимоотношения с работниками в поместье. Кубрин несколько раз довольно пренебрежительно отзывается о своих работниках: «Каждый день по стакану крови своей порчу... Я положил за правило себе: всегда делать как раз наоборот тому, что говорят мне работники. Только так и можно уберечься от их хитростей» [Абрамова, 1885, с. 640]. Тем не менее, как мы видим, главная его претензия - необходимость всегда быть «начеку», поскольку и работники, и сам барин заботятся каждый о своих интересах. В данном случае предприимчивость хозяина вступает в противоречие с желанием работников соблюсти свои интересы. Причем крестьян Кубрин делит на два типа: те, у кого главная выгода - ничего не делать, и те, кто «мужик честный», кому «можно помочь» [Абрамова, 1885, с. 642]. Более того, в опубликованном очерке Кубрин советуется с мужиком Прасолом, у которого «учился хозяйничать» [Абрамова, 1885, с. 656] и который, по образному выражению автора, «... один из тех редких, сильных и практических умов, которые встречаются и между мужиками и которых настоящее назначение - делать большое дело» [Абрамова, 1885, c. 656]. Об уважительном отношении к крестьянам читаем и в очерке «Из воспоминаний циклиста», опубликованном в 1903 году в «Русской мысли» и описывающем диалог между автором и нотариусом из Польши, который смог завоевать доверие некоего Дзенгеля - «дикого мужика»: «Вопервых, я никогда не юлил перед ним, как это иногда делают господа из интеллигенции. А, во-вторых, в отношениях с ним и вообще с мужиками я никогда не навязывал своих вкусов, но всегда старался служить их интересам... Вы думаете, что указать крестьянину путь к благосостоянию, влияние не моральное?» [Прус, 1903, с. 91].

Кстати говоря, урядник из очерка о Кубрине совсем не видит сложности в стилях поведения крестьян, о котором говорит главный герой, от- 
мечая только лень и невежество мужиков: «Что им хозяйское добро! Им бы только спать да пьянствовать вволю» [Абрамова, 1885, с. 640]. Подобное же мнение выражено С. Матвеевым в очерке «Из жизни современного крестьянского мира»: «Альфонцев жалуется и упрекает меня, что я избаловал народ. Он говорит, что, бывало, они не шлялись, что их не переслушаешь и их дел вовеки не распутаешь; что они врут все и сами не знают, чего им надо, а нечего делать, вот и шляются» [Матвеев, 1916, с. 119].

Несколько иной образ отношений дворян и крестьян представлен в воспоминаниях князя С. Е. Трубецкого «Минувшее» [Трубецкой, 1991], подробно описывавшего взаимоотношения деда - князя А. А. Щербатова с крестьянами его поместья - села Хорошее, в котором, по воспоминаниям автора, еще сохранились черты старого уклада жизни. Князь Александр Алексеевич Щербатов (1829-1902 гг.), как известно, с 1863 по 1869 годы являлся первым всесословно выборным московским городским головой, известным благотворителем [Щербатов, 2009]. В основном проживал в селе Хорошее, находившемся с 1802 года в Павлоградском уезде Екатеринославской губернии. Губерния имела относительно высокий уровень плотности населения - наличное городское и сельское население в 1897 году составило 1872,7 тыс. чел. [Сельское хозяйство ..., 1923, с. 18]. В этих условиях остро вставал вопрос о смене условий повседневной жизни как дворян, так и крестьян. А. А. Щербатов являлся ярким представителем дворянского сословия, старавшегося сохранить видимость «старого порядка».

Данной цели служил, по воспоминаниям С. Е. Трубецкого, традиционный «выход» деда на подъезд с колоннами хорошевского дома со всей семьей встречать крестьян, приветствовать их хлебом с солью. Эта традиция была обустроена разными деталями, не меняющимися из года в год: слова приветствия с крыльца, чинные поклоны баб, общение с мужиками в толпе об урожае, обязательное угощение. Хорошевскими крестьянами хозяин поместья воспринимался в качестве отца, второго родителя. Это проявлялось в церемонии деревенских свадеб, которые обязательно заезжали в господский дом, чтобы молодая чета могла просить благословения. Сам А. А. Щербатов поддерживал такие отношения: «Дедушка всегда неизменно лично принимал свадьбы и никогда не сокращал времени приема, хотя б и плохо себя чувствовал; он считал, что не имеет права от этого уклоняться» [Трубецкой, 1991, с. 34]. А. А. Щербатов, по воспоминаниям С. Е. Трубецкого, чувствовал себя «отцом крестьян», обязанным заботиться о них в меру своих сил и возможностей, последние, впрочем, были действительно велики. Несмотря на то, что сам Щербатов был сторонником освобождения крестьян от крепостной зависимости и горячо поддерживал реформы Александра II, он считал необходимым сохранять 
традиционный уклад жизни в поместье: «Крестьяне уже были не “его”, но он по-прежнему оставался “их” барином» [Трубецкой, 1991, с. 35]. Князь А. А. Щербатов строил просторные церкви в своих имениях, но кроме этого - школы и больницы, чаще каменные, чтобы уберечь от пожаров. Он помогал нуждающимся, не афишируя свою помощь, приобщал крестьян к русской культуре. Так, в новой школе в Хорошем была выстроена большая зала для «народных чтений» с волшебным фонарем.

Таким образом, к началу XX века сформировались три образа отношений дворян и крестьянства: предпринимательский «новый тип», «попечительский тип», «барский» тип. Представители каждого из этих образов исходили из собственных суждений о благе и интересах, которые часто не совпадали ни с самоидентификацией конкретного дворянина или крестьянина, ни с взаимными представлениями друг о друге.

\section{3. Земские либералы, либеральная профессорская и творческая интеллигенция: сравнительный анализ их представлений о роли российского крестьянства в развитии России}

На 1895 год сумма расходов всех земских губерний составляла 65 880,751 тыс. руб. [Антропов, 1989, с. 65] Следует согласиться с Н. С. Цинцадзе, что восприятие земцами условий жизни крестьян отличалось высокой степенью заинтересованности, понимания и сочувствия. Крестьянство в отличие от земцев, чиновников, помещиков, ученых, писателей и др., которых эти проблемы касались косвенно, воспринимало свое хозяйственное неустройство наиболее эмоционально [Цинцадзе, 2012, с. 247].

Александр Александрович Корнилов (1862-1925 гг.), историк и секретарь ЦК конституционно-демократической партии, представляет собой один из подобного рода примеров поместного дворянина, чье отношение к крестьянам, сформировавшееся в условиях семейного окружения, университетской среды, было неоднократно «проверено» в непосредственном общении с крестьянами. Как известно, А. А. Корнилов некоторое время служил комиссаром по крестьянским делам Конского уезда Радомской губернии [Галимзянова, 2018, с. 126-135]. В апреле 1887 года, в первое же утро пребывания в должности, в квартире гминного писаря Таневского молодой мужик принес принадлежности для умывания и заученным движением потянулся целовать руку писаря. А. Корнилов высказал возмущение и указал на недопустимость подобного поведения. Во время разговора с мужиком оказалось, что последний являлся войтом общины, то есть волостным старшиной, у которого в подчинении был писарь Таневский. Но войт был из крестьян и потому целовал руку писарю: «Писари же в качестве грамотеев весьма часто шляхетского происхождения, величались над ними, давали им 
целовать свою руку и относились к ним (к войтам), как к обыкновенному крестьянству, которое было с их точки зрения попросту “быдлом”» [Корнилов, 1994, с. 150]. Интересно, что принципиальную позицию А. Корнилова не поняла не только шляхта, но и сами крестьяне. Объяснить им, что целование рук - это унижение собственного достоинства, а все люди равны, было невозможно. В этом А. Корнилов убедился, нечаянно подслушав разговор нескольких крестьян у себя в приемной: «И почему это пан комиссар не любит дать поцеловать себе руку или коленку?.. Понятно, потому что он такой гордый человек, что не желает, чтобы до него всякий дотрагивался» [Корнилов, 1994, с. 151]. Действительно, у мужиков была «своя правда», и дело было даже не в «целовании коленки». В Центральной России считалось, например, что «посадить в старосты» значило то же самое, что «отдать в солдаты или разорить», и смекалистые мужики стремились «освободиться от этой почетной должности» [Матвеев, 1916, с. 122]. К этому времени возможность вести крепкое хозяйство у крестьян ценилась выше административных должностей, которые не давали дохода и отбирали драгоценное время, необходимое для ведения сельских дел. И в этом плане позицию дворян, ушедших в земское движение, выразил Б. Прус на страницах «Русской мысли» в 1903 году: «Уверяю вас < ..> по долголетней практике я знаю, что, когда мужику не грозит голод, когда у него есть порядочная хата и кой-какие денежки, он сейчас же выписывает Праздничную Газету или Зарю, обучает детей грамоте и становится таким же хорошим гражданином, как и мы с вами. Правда, он не декламирует, не болтает, но это не мешает ему быть хорошим гражданином» [Прус, 1903, с. 91].

В этом плане взгляды поздних земцев во многом сходились с представлениями либеральной профессорской интеллигенции о крестьянстве. Например, М. М. Ковалевский в своих лекциях, прочитанных в Тейлоранском институте в Оксфорде в 1889-1890 годах и опубликованных в Лондоне под названием «Modern customs and ancient lows of Russia», остановился на характеристике «специфического вида семейного коммунизма» в России - на домашней общине, представляющей собой «неразделенное землевладение» и определяющей менталитет российского крестьянства психологию взаимозависимости, общинности [Kovalevsky, 1891, p. 47, 49]. Древние общинные институты, по мнению М. Ковалевского - главная причина нищеты в стране: «Я думаю, что русский крестьянин не лишен тяги к индивидуализму, что хорошо доказывает раздел от 2 до 3 млн домашних общин после 1861 года» [Kovalevsky, 1891, p. 65]. Тот факт, что до отмены крепостного права раздел общин происходил значительно реже, М. Ковалевский объясняет фискальными интересами государства, оставаясь на позициях, согласно которым народ был не готов к собственному 
«поведению» и «принятию решений»: «Они остаются без естественного контроля и руководства просвещенных классов» [Kovalevsky, 1891, p. 99100]. М. Ковалевский также подробно описывал будущее развития общинного института в России: «Община исчезнет в России, как исчезла она в Европе. Она уступит место частной собственности на землю тогда, когда пойдет принципиальное трансформирование в капитале... Но это дело далекого будущего...» [Kovalevsky, 1891, p. 118]. В данном подходе он весьма напоминает «попечительский образ» отношений между дворянами и крестьянами, представленный ранее портретом князя А. А. Щербатова.

В работах М. М. Ковалевского мы находим подробное описание взглядов на крестьянство и общественно-политические убеждения в целом многих известных представителей культурной и политической элиты конца XIX - начала XX веков, в частности, Г. И. Успенского, Н. Н. Златовратского, И. С. Тургенева, Л. Н. Толстого. Определяя круг собственных симпатий во взглядах на роль крестьянства в России, М. Ковалевский писал, что два великих русских писателя - Г. Успенский и Н. Златовратский известны в России почти так же, как И. Тургенев и Л. Толстой. Однако Н. Златовратский и Г. Успенский, по мнению автора, рисовали две разные картины крестьянской жизни, два типа русского крестьянства. Г. Успенский видел в крестьянине человека, живущего в регламенте сельскохозяйственного труда и морально, и этически. Парадокс его жизни заключался в том, что пока он собственник, его мораль здорова, но стоит ему потерять хотя бы кусочек земли, как он становится дебоширом, пьяницей и т. д. По мнению Л. В. Селезневой, Н. Златовратский противопоставлял ему тип крестьянина-философа, который считает, что продукты земли принадлежат всем людям, а главная обязанность христианина - помогать соседям [Селезнева, 1995, с. 59-60]. М. Ковалевский признавал правомерность существования обоих типов, изображенных писателями, их одинаковую жизненность в России, но отмечал, что авторы изобразили разные этапы крестьянской исторической эпохи: первый тип - крестьянин, вышедший из общины, второй — находящийся в ней крестьянин-общинник.

И. С. Тургенев, однако, являл собой характерный тип российского дворянина, который, отгородившись от «попечительской» манеры взаимоотношений, предпочел поддержать крестьян, признавая их самостоятельность после освобождения. Так, например, в письме критику, историку литературы и библиографу С. А. Венгерову из Спасского летом 1874 года И. С. Тургенев сообщал о том, что при освобождении своих крестьян он не взял с них денег за усадебную землю, «что составляло крупную сумму», при выкупе везде уступил им пятую часть земли и угодий, см.: [Цинцадзе, 2012, с. 243]. Учитывая, что в пятидесяти губерниях Европейской России 
общее количество всей крестьянской надельной земли, или находящейся по некоторым губерниям во владении сельских обществ, простиралось до 127 388,975 дес. и, следовательно, при сопоставлении общей суммы всех мирских расходов с крестьянской землей оказывалось, что средний размер расходов на одну десятину достигал в Европейской России 35 коп. [Антропов, 1898, с. 7], поступок И. С. Тургенева должен был стать действительным подспорьем для его крестьян в новой жизни.

Компромиссным подходом можно считать концепцию П. Б. Струве, изложенную в статье «Мужики» Г. Чехова» (опубликована в сборнике «На разные темы» (1893-1901). П. Б. Струве писал, что освобождение от власти земли и мирского строя являлось движением вперед, которое в любом случае слагалось из нарушений равновесия. В преобразовании духовного склада в деревне участвовали два отдаляющихся друг от друга слоя. Причиной данного отдаления являлись новые экономические отношения, вторгшиеся в деревню, а также увеличение городского влияния, разрушившего власть земли. П. Струве отмечал двойственность влияния хозяйственной борьбы на личность: победа в этой борьбе являлась необходимым условием роста личности, но и одновременно способствовала утере личностного начала [Струве, 2014, с. 121-132]. Вместе с тем именно П. Струве принадлежит идея о закрывшейся после революции 1905 года «пропасти» между интеллигенцией и народом и «ответственности» интеллигенции за то, что она привнесла в народ: «О том, что между народом и интеллигенцией существует идейная пропасть, в настоящее время могут говорить только черносотенцы или те черносотенцы наизнанку, которые, по-видимому, рекрутируются из бывших декадентских кругов <..> идеи интеллигенции поразительно быстро проникли в народные массы и действенно заразили их» [Струве, 1999, с. 83].

Таким образом, земские либералы, профессорская и творческая интеллигенция, в целом не только и не столько интуитивно, но исходя из собственного опыта освобождения крестьян из крепостной зависимости, представили характеристики крестьянина-общинника и крестьянина земельного собственника. Важнейшим итогом постепенного превращения из общинника в собственника стало осознание крестьянином собственного «Я» как свободной личности и полноправного участника политических отношений.

\section{4. Заключение}

Итак, мемуары А. А. Корнилова «Воспоминания ученого-историка» и С. Е. Трубецкого «Минувшее» интересны с точки зрения выявления взглядов российского дворянства на жизнь и будущее крестьянина, его роль в соци- 
ально-экономическом развитии страны. При этом если мемуары С. Е. Трубецкого рисуют перед нами картину помещичье-крестьянского провинциального быта и отражают формирование взглядов помещика-либерала, то воспоминания А. А. Корнилова представляют позицию в отношении крестьянства человека, большую часть жизни посвятившего земскому движению. Лекции М. М. Ковалевского позволяют проследить отношение к крестьянской общине как к особой форме социальных отношений в России. Произведения Г. Успенского, И. Тургенева и других представителей творческой интеллигенции отражают процесс нравственно-психологического погружения российской интеллигенции в крестьянский мир. Наконец, именно на страницах наиболее известных и читаемых либеральных журналов конца XIX — начала XX веков — в «Вестнике Европы» и в «Русской мысли» представители передового дворянства публиковали рассказы, очерки, аналитические материалы, переписку, на примере которых мы можем проследить развитие мировоззрения либерально настроенного дворянства на изменение места и роли крестьянства в пореформенной России.

Таким образом, основываясь на анализе представленных источников, можно выделить различные образы отношений дворянства и крестьянства в России на рубеже XIX-XX веков. В частности, описываемый выше Кубрин олицетворяет собой образ «нового предпринимательского типа», в рамках которой главный герой, учитывавший изменившиеся социальноэкономические условия, новый статус российского крестьянства и видевший процессы расслоения в нем, опирался на тот слой мужиков, которые проявляли «смекалку» и соответствовали предприимчивому характеру самого помещика. На примере Кубрина мы видим тот тип российского дворянства, который был готов идти «на выучку к мужику». В отличие от Кубрина А. А. Щербатов принадлежал к «зубрам» поместного дворянства, соответственно, главной чертой взаимоотношений с крестьянами являлись «попечительство» и «сохранение традиций». А. Щербатов так же, как и Кубрин, не только понимал и признавал необходимость отмены крепостного права, но и осознавал происходившие необратимые изменения в российском крестьянстве и в сельской среде в целом. Однако, считая их чересчур резкими, старался оградить российского мужика от стремительных изменений внешнего мира, неизбежно грозящих последнему, по его мнению, разорением и иными бедами. Третий условный образ отношений - «барский» - основан на представлениях дворян, которые в силу различных причин не видели или не хотели признавать произошедших с российским крестьянством изменений. Их отношение к крестьянам определялось нежеланием признавать в том числе и новый статус собственного сословия. Дворяне - участники земского движения - ставили целью не просто 
просвещение российского крестьянства, но в том числе политическое просвещение, которое должно было основываться на достатке каждого конкретного крестьянина и его уверенности в завтрашнем дне. Профессорская и творческая интеллигенция составили еще один образ отношений, который можно условно назвать образом «свободного действия». Его характерной чертой являлось представление о крестьянине как самостоятельном субъекте общественной жизни, способном не только к экономическому, но и к политическому творчеству. При этом как среди участников земского движения, так и среди профессорской и творческой либеральной интеллигенции на рубеже XIX - XX веков по-прежнему сохранялись отдельные черты выделенных нами иных образов отношений между дворянством и крестьянами.

\section{Источники}

1. Абрамова В. Люди провинции / В. Абрамова // Вестник Европы. - 1885. - Август. - С. $626-657$.

2. Антропов П. А. Финансово-статистический атлас России : Наглядное графическое изображение финансового состояния России / сост. по офиц. данным П. А. Антропов. - Санкт-Петербург : А. Ф. Маркс, 1898. - 79 с.

3. Корнилов А. А. Воспоминания / А. А. Корнилов // Вопросы истории. - 1994. № 2. - C. $143-159$.

4. Матвеев С. Из жизни современного крестьянского мира / С. Матвеев // Русское богатство. - 1916. - Сентябрь. - С. 116-142.

5. Прус Б. Из воспоминаний циклиста / Б. Прус // Русская мысль. - 1903. - Сентябрь. - С. $71-118$.

6. Сельское хозяйство России в XX веке : сборник статистико-экономических сведений за 1901-1922 годы. - Москва : Изд-во Наркозема, 1923. - 31 с.

7. Струве П. Б. Интеллигенция и народное хозяйство / П. Б. Струве / Избранные сочинения. - Москва : РОССПЭН, 1999. - С. 80-85.

8. Струве П. Б. На разные темы. (1893-1901 гг.) : сборник статей / П. Б. Струве Москва : Книга по Требованию, 2014. - 562 с.

9. Трубецкой С. Е. Минувшее / С. Е. Трубецкой. — Москва : ДЭМ, 1991. — 328 с.

10. Kovalevsky M. Modern customs and ancient lows of Russia / M. Kovalevsky. — London : David Nutt, 1891. - 269 p.

\section{ЛитеРАТУРА}

1. Баландина Э. Г. Между властью и народом. Самосознание русской интеллигенции / Э. Г. Баландина // Россия в новое время. Образованное меньшинство и крестьянский мир: поиск диалога : материалы межвузовской научной конференции, 21-22 апреля 1995 г. - Москва : РГГУ, 1995. — С. 7-9.

2. Бахманн-Медик Д. Культурные повороты : новые ориентиры в науках о культуре / Д. Бахманн-Медик. - Москва : Новое литературное обозрение, 2017. - 504 с.

3. Блок М. Апология истории, или Ремесло историка / М. Блок ; пер. с фр. Е. М. Лысенко. — Москва : Наука, 1986. — 174 с. 
4. Конструирование истории. Кто мы? / М. С. Бобкова, М. П. Айзенштат, Г. Е. Гиголаев, С. Г. Мереминский, А. И. Сидоров, К. И. Софронов, А. А. Улунян. - СанктПетербург : Евразия, 2019. - 320 с.

5. Галимзянова E. А. Из Царства Польского в Моршанский уезд : А. А. Корнилов и Приютинское братство в борьбе с голодом 1891-1892 гг. / Е. А. Галимзянова // Славянский альманах. — 2018. — № 3-4. — C. 126-135. — DOI: 10.31168/2073-5731.2018.3-4.1.10.

6. Дмитриева Н. В. Научный семинар «Общественное движение в российской империи: участники, структуры, идеи» (Ростов-на-Дону, 27 января 2020 г.) / Н. В. Дмитриева, К. Р. Мухаметшина // Новое прошлое = The New Past. — 2020. — № 1. — C. 292 299. - DOI: 10.18522/2500-3224-2020-1-292-299.

7. Кузьмин A. B. Взаимная идентификация крестьян и дворян России конца XIX начала XX вв. : автореф. дис. ... канд. истор. наук / А. В. Кузьмин. - Тамбов, 2007. $24 \mathrm{c}$.

8. Либерализм в России : сб. ст. / отв. ред. В. Ф. Пустарнаков, И. Ф. Худушина. Москва : ИФРАН, 1996. — 448 с.

9. Логунов А. П. Образованное меньшинство и крестьянский мир: проблемы раскола и диалога / А. П. Логунов // Россия в новое время. Образованное меньшинство и крестьянский мир: поиск диалога : материалы межвузовской научной конференции, 21-22 апреля 1995 г. — Москва : РГГУ, 1995. - С. 3-6.

10. Лотман Ю. М. Понятие границы / Ю. М. Лотман // Внутри мыслящих миров : Человек-текст-семиосфера-история. - Москва : Языки русской культуры, 1996. $464 \mathrm{c}$

11. Маловичко С. И. Современная историческая наука и изучение локальной истории / С. И. Маловичко, Т. А. Булыгина // Новая локальная история: методы, источники, столичная и провинциальная историография : материалы первой Всероссийской Интернет-конференции. - Ставрополь, 2003. - 262 с.

12. Миронов Б. Н. Благосостояние населения и революции в имперской России: XVIII — начало XX века / Б. Н. Миронов. - Москва : Новый хронограф, 2010. — 911 с.

13. Могильнер М. Ното imperii: История физической антропологии в России (конец XIX — начало XX вв.) / М. Могильнер. - Москва : Новое литературное обозрение, 2008. $-512 \mathrm{c}$.

14. Островский A. В. О степени социального расслоения в дореволюционной России / А. В. Островский // Русская революция 1917 г.: проблемы истории и историографии : сб. докладов Межвузовской научной конференции. - Санкт-Петербург : Изд-во СПбГЭТУ ЛЭТИ, 2013. - С. 136-144.

15. Пирумова Н. М. Земская интеллигенция и ее роль в общественной борьбе до начала XX в. / Н. М. Пирумова ; отв. ред. В. Я. Лаверычев ; АН СССР, Ин-т истории СССР. - Москва : Наука, 1986. - 268 с.

16. Пономарева М. А. П. Б. Струве в эмиграции (развитие концепции либерального консерватизма) : дис. ... канд. истор. наук / М. А. Пономарева. - Ростов-на-Дону, 2004. - $214 \mathrm{c}$.

17. Российский либерализм: идеи и люди / отв. ред. и сост. А. Кара-Мурза. — Москва : Новое изд-во, 2004. - 613 с.

18. Селезнева Л. В. Российские либералы начала XX века о судьбах общины и тенденциях крестьянской ментальности / Л. В. Селезнева // Россия в новое время. Образованное меньшинство и крестьянский мир: поиск диалога : материалы межвузовской научной конференции, 21—22 апреля 1995 г. — Москва : РГГУ, 1995. - С. 59-60. 
19. Цинцадзе Н. С. Демографические и экологические проблемы развития аграрного общества России во второй половине XIX — начале XX века в восприятии современников / Н. С. Цинцадзе. - Тамбов : Издательский дом ТГУ им. Г. Р. Державина, 2012. - $286 \mathrm{c}$.

20. Черменский Е. Д. Буржуазия и царизм в революции $1905-1907$ гг. / Е. Д. Черменский. - Москва ; Ленинград : Гос. соц.-экон. изд-во, 1939. - 374 с.

21. Шаповалов B. A. Формирование нового социального статуса у представителей различных сословий Российской империи в условиях деструктурирования сословного строя пореформенного периода (социально-психологический аспект) / В. А. Шаповалов, К. Н. Лобанов // Научные ведомости Белгородского государственного университета. Серия: История. Политология. — 2012. — № 13 (123). — С. 99-104.

22. Шацилло К. Ф. Русский либерализм накануне революции 1905-1907 гг. Организация. Программы. Тактика. - Москва : Наука, 1985. - 354 с.

23. Щербатов А. А. На службе Москве и Отечеству / А. А. Щербатов. - Москва : Русскій міръ, 2009. - 528 с.

24. Mills C. W. The power elite / Wright Mills. - New York : Oxford university press, 1956. $-423 \mathrm{p}$.

\section{Material Resources}

Abramova, V. (1885). People of the province. In: Bulletin of Europe, August: 626-657. (In Russ.).

Agriculture of Russia in the XX century: a collection of statistics and economic data for 1901-1922. (1923). Moskva: Izd-vo Narkozema. 31 p. (In Russ.).

Antropov, P. A. (1898). Financial and Statistical Atlas of Russia: A clear graphic representation of the financial condition of Russia. St. Petersburg: A. F. Marks. 79 p. (In Russ.).

Kornilov, A. A. (1994). Memories. Issues of History, 2: 143-159. (In Russ.).

Kovalevsky, M. (1891). Modern customs and ancient lows of Russia. London: David Nutt. $269 \mathrm{p}$.

Matveev, S. (1916). From the life of the modern peasant world. In: Russian wealth, September: 116-142. (In Russ.).

Prus, B. (1903). From the memories of the cyclist. In: Russian thought, September: $71-118$. (In Russ.).

Struve, P. B. (1999). Intelligentsia and the National Economy. In: Selected Works. Moscow: ROSSPEN. 80-85. (In Russ.).

Struve, P. B. (2014). On different topics. (1893-1901): collection of articles. Moscow: Kniga po Trebovaniyu. 562 p. (In Russ.).

Trubetskoy, S. E. (1991). Past. Moscow: DEM. 328 p. (In Russ.).

\section{REFERENCES}

Balandina, E. G. (1995). Between the government and the people. Self-awareness of the Russian intelligentsia. In: Russia in modern times. The educated minority and the peasant world: the search for dialogue: materials of the interuniversity scientific conference. Moscow: RGGU. 7-9. (In Russ.).

Bachmann-Medick, D. (2017). Cultural turns: new landmarks in cultural sciences. Moscow: Novoe literaturnoe obozrenie. 504 p. (In Russ.). 
Bloch, M. (1986). Apologie pour l'histoire ou Métier d'historien. Moscow: Nauka. 174 p. (In Russ.). Bobkova, M. S., Ayzenshtat, M. P., Gigolaev, G. E., Mereminskiy, S. G., Sidorov, A. I., Sofronov, K. I., Ulunyan, A. A. (2019). History construction. Who are we? St. Petersburg: Evraziya. 320 p. (In Russ.).

Chermenskiy, E. D. (1939). The bourgeoisie and tsarism in the revolution of 1905-1907. Moscow; Leningrad: Gos. sots.-ekon. izd-vo. 374 p. (In Russ.).

Dmitrieva, N. V., Mukhametshina, K. R. (2020). Research seminar "Social movement in the Russian empire: participants, structures, ideas". The New Past, 1: 292-299. DOI: 10.18522/2500-3224-2020-1-292-299. (In Russ.).

Galimzyanova, E. A. (2018). From the Kingdom of Poland to the Morshansk district: A. A. Kornilov and the Priyutinskoe brotherhood in the fight against the famine of 1891-1892. Slavic almanac, 3-4: 126-135. DOI: 10.31168/20735731.2018.3-4.1.10. (In Russ.).

Kara-Murza, A. (ed.). (2004). Russian liberalism: ideas and people. Moscow: Novoe izd-vo. 613 p. (In Russ.).

Kuzmin, A. V. (2007). Mutual identification of peasants and nobles in Russia at the end of the $19^{\text {th }}$ - beginning of the 20th centuries: author's abstract of PhD Diss. Tambov. 24 p. (In Russ.).

Logunov, A. P. (1995). The educated minority and the peasant world: problems of schism and dialogue. In: Russia in modern times. The educated minority and the peasant world: the search for dialogue: materials of the interuniversity scientific conference. Moscow: RGGU. 3 -6. (In Russ.).

Lotman, Yu. M. (1996). Border concept. In: Inside Thinking Worlds: Man-Text-SemiosphereHistory. Moscow: Yazyki russkoy kultury. 464 p. (In Russ.).

Malovichko, S. I., Bulygina, T. A. (2003). Contemporary Historical Science and the Study of Local. In: History New Local History: methods, sources, metropolitan and provincial historiography: materials of the first All-Russian Internet conference. Stavropol. 262 p. (In Russ.).

Mills, C. W. (1956). The power elite. New York: Oxford university press. 423 p.

Mironov, B. N. (2010). Population welfare and revolutions in imperial Russia: $18^{\text {th }}$ - early 20th centuries. Moscow: Novyy khronograf. 911 p. (In Russ.).

Mogilner, M. (2008). Homo Empire: History of Physical Anthropology in Russia (late $19^{\text {th }}$ early 20th centuries). Moscow: Novoe literaturnoe obozrenie. 512 p. (In Russ.).

Ostrovskiy, A. V. (2013). On the degree of social stratification in pre-revolutionary Russia. In: Russian revolution of 1917: problems of history and historiography: collection of articles. reports of the Interuniversity Scientific Conference. St. Petersburg: Izd-vo SPbGETU LETI. 136-144. (In Russ.).

Pirumova, N. M. (1986). Zemskaya intelligentsia and its role in social struggle until the beginning of the twentieth century. Moscow: Nauka. 268 p. (In Russ.).

Ponomareva, M. A. (2004). P. V. Struve in emigration (development of the concept of liberal conservatism): PhD Diss. Rostov-na-Donu. 214 p. (In Russ.).

Pustarnakov, V. F., Khudushina, I. F. (eds.). (1996). Liberalism in Russia: collection of articles. Moscow: IFRAN. 448 p. (In Russ.).

Selezneva, L. V. (1995). Russian liberals of the early twentieth century on the fate of the community and tendencies of the peasant mentality. In: Russia in modern times. The educated minority and the peasant world: the search for dialogue: materials of the interuniversity scientific conference. Moscow: RGGU. 59-60. (In Russ.). 
Shapovalov, V. A., Lobanov, K. N. (2012). Formation of a new social status among representatives of various estates of the Russian Empire in the context of the destructuring of the estate system of the post-reform period (socio-psychological aspect). Scientific bulletin of Belgorod State University. Series: History. Political science, 13 (123): 99-104. (In Russ.).

Shatsillo, K. F. (1985). Russian liberalism on the eve of the 1905-1907 revolution. Organization. Programs. Tactics. Moscow: Nauka. 354 p. (In Russ.).

Shcherbatov, A. A., prince. (2009). In the service of Moscow and the Fatherland. Moscow: Russkiy mir. 528 p. (In Russ.).

Tsintsadze, N. S. (2012). Demographic and environmental problems of the development of the agrarian society of Russia in the second half of the XIX-early XX century in the perception of contemporaries. Tambov: Publishing house TGU im. G. R. Derzhavina. 286 p. (In Russ.). 